\title{
In memoriam: Gebhard Kirchgässner (April 15, 1948-April 1, 2017)
}

\author{
Lars P. Feld ${ }^{1}$
}

Received: 24 April 2017/Accepted: 26 April 2017/Published online: 10 May 2017

(C) Springer Science+Business Media New York 2017

Public choice reasoning applies the economic model of human behavior to non-market, especially political, decision-making. When Buchanan and Tullock published the Calculus of Consent in 1962, they had already written several papers on the public choice paradigm. It took nearly another 10 years before their ideas spilled over into Europe. In 1971, Peter Bernholz, Bruno S. Frey, Elisabeth Liefmann-Keil and Gordon Tullock established the European Public Choice Society (EPCS). ${ }^{1}$ The school founded by Bruno Frey has since been in the core of the EPCS. Early members of the Zurich (Frey) school of Public Choice were Beat Blankart, the late Werner Pommerehne, Friedrich Schneider and the late Gebhard Kirchgässner.

After studying economics at the University of Konstanz, where he also finished his $\mathrm{PhD}$ and his habilitation, along with a post-doctoral position at the ETH Zurich, Kirchgässner was Professor of Economics, in particular Public Economics, at the University of Osnabrück from 1982 to 1994. From 1992 until his retirement in 2013, he was Professor of Economics and Econometrics at the University of St. Gallen and Director of the Swiss Institute of International Economics and Applied Economic Research.

Gebhard was a very active member of the EPCS, not only as its president from 2003 to 2005 but also in connection with his scholarly research program. In the 1970s and 1980s, he worked on political business cycles and popularity vote functions. His dissertation (Kirchgässner 1976) and habilitation (Kirchgässner 1984a) were on these subjects, but he published extensively on related topics during his whole academic career (e.g., Kirchgässner 1983a, 1984b, 1985a, b, 1991a). Actually, Gebhard never lost interest in voting and government popularity as central themes to Public Choice (Feld and Kirchgässner 2000a; Kirchgässner 2009). According to his empirical results, unemployment, and sometimes price inflation or even hidden unemployment, consistently influenced

\footnotetext{
1 See Peter Bernholz, "Gordon Tullock, The Flying Ambassador", mimeo, http://publicchoice.info/ TullockTales/Bernholz.pdf (download at March 30, 2010).
}

Lars P. Feld

feld@eucken.de

1 Walter Eucken Institut, University of Freiburg, Goethestr. 10, 79100 Freiburg i. Br., Germany 
the popularity of German governments. He reported only one exception: For the Schröder government, Gebhard could not establish a robust effect (Kirchgässner 2009). One of the last papers he would finish was a survey on voting and popularity (Kirchgässner 2016a).

His interests in voting and rational choice broadened, beginning in the 1980s, into studies of the paradox of voting. The differences between actual election turnout rates and the ones predicted by rational choice models remains a challenge for the public choice research program. Kirchgässner contributed to that literature by analyzing the extent to which electoral closeness matters for voter turnout rates at the margins (Kirchgässner and Schimmelpfennig 1992; Kirchgässner and Meyer zu Himmern 1997).

In comparison with Brennan and Lomasky's (1993) expressive voting theory, Kirchgässner (1992) developed a theory of low-cost electoral choices. Relative to instrumental voting (Downs 1957), which holds that voters elect parties or candidates in order to obtain political outcomes close to their own self-interests, expressive voting theory argues that voters express only their sympathy or discontent with the available ballot options, like cheering for a sports team. Expressive voting behavior appears to be easier to manipulate than instrumental voting motives and is morally agnostic. In Kirchgässner's low-cost decision theory, moral behavior has a better chance of becoming dominant. Two types of low-cost decisions are possible: those in which a person makes a choice that has no effect on himself or herself personally, but a large effect on other individuals-judges often face that same situation - and the choices which must often be taken at the ballot box in which an individual decides without any effect on his/her welfare, but on the general collective good, like in elections. Kirchgässner argues that in such situations individuals have low costs of behaving morally. If individuals adopt moral norms during their socialization process or if peer groups enforce certain moral norms, the low-cost decision is shaped by soft incentives. Kirchgässner (2010) extends this argument to a theory of minimal morals.

When probabilistic voting models became more popular in public choice and political economy in the 1990s and 2000s, Kirchgässner appeared to be unconvinced that they really provide a solution for the classical voting cycle problem in social choice. Kirchgässner (2000) proves that similar restrictions on policy space are necessary to avoid cycles and manipulation by agenda setters, as in the classical case of Arrow's impossibility theorem.

Kirchgässner studied differences in policy outcomes induced by different constitutional frameworks in the sense that is popular today in the realm of comparative political economics. His work on tax competition, fiscal federalism and decentralization may be located in traditional public economics or public choice (Kirchgässner and Pommerehne 1976, 1996; Feld and Kirchgässner 2003). Indeed, Brennan and Buchanan's (1980) Leviathan model is at least lurking in the background of these analyses (see Feld et al. 2010b). His papers on the effects of direct democracy clearly adopt a comparative perspective. Feld and Kirchgässner (1999, 2001a, b) and Feld et al. (2011) analyzed the impact of referendums on public spending, revenue, budgets deficits and accumulated debt. Feld et al. (2010a) takes a closer look at how referendums and popular initiatives affect the welfare state. Dorn et al. (2008) studied happiness and direct democracy. In addition, Kirchgässner contributed to research on the institutions of direct democracy in several surveys (Kirchgässner et al. 1999; Feld and Kirchgässner 2000b), up to and including one of his most recent papers (Kirchgässner 2016b). Such comparative research also aligns with his studies on the effects of fiscal institutions on fiscal policy outcomes (Feld and Kirchgässner 2008; Kirchgässner 2013a, 2014a, 2017a).

In recent times, Kirchgässner pushed public choice applications of the economic model of human behavior further to study economic policy advisors. Traditional welfare economics, but also much of macroeconomics, view economic policy advisors as suggesting 
the right policies to correct market failures or stabilize economies, implicitly assuming that the advisors themselves and the officials to which the advice is directed are always interested in the truth, almost altruistically following what economic analysis tells them. Although he started working some years earlier on those questions (Kirchgässner 1996), he only recently returned to the notion of the self-interested economic policy advisor so as to push it further (Kirchgässner 2014b). In good public choice tradition, he shows, supported by several pieces of evidence, that economic policy advisors follow their self-interests, restricted mainly by reputational concerns. As Kirchgässner was a member of the Swiss Council of Economic Experts (Kommission für Konjunkturfragen) from 1997 to 2007 (from 2004 to 2007 as its president), and advised the Swiss government and parliament on tax, fiscal and health policies, he could draw much on his own experiences. He planned to combine that experience as a policy advisor together with the insights gained from his scholarly research into a new book, but was not afforded the time necessary to finish the project. It would have been interesting to see the extent to which he would have distinguished the market for policy advice from institutionalized advisory bodies additionally restricted by their mandates and subject to much more public attention.

Acknowledging Kirchgässner's achievements in public choice, political economics or constitutional political economy would not do justice to his scientific legacy. His interests in methodological questions were enormous. His book on the economic model of human behavior, Homo oeconomicus (Kirchgässner 1991b, 2008), is one of his most cited works. He continued to work in this field until recently (Kirchgässner 2013b). In these and other publications, Kirchgässner demonstrates the usefulness and boundaries of the economic model of human behavior.

Moreover, Kirchgässner was an econometrician, finishing his other (earlier) habilitation in econometrics (Kirchgässner 1981). Although his research covered the whole range of (applied) econometrics, his main passion was time series econometrics (Kirchgässner and Wolters 1992; Kirchgässner 1993; Kirchgässner and Müller 2006), on which, together with Jürgen Wolters, he published a textbook (Kirchgässner and Wolters 2007).

Finally, Kirchgässner contributed to a large number of topics from economic policy and public economics to which I can only refer selectively. Some of his most successful publications were in monetary economics (Kirchgässner and Wolters 1987, 1995), but he also contributed to fiscal policy topics (Kirchgässner and Pommerehne 1997; Kirchgässner and Prohl 2008), environmental and energy economics (Kirchgässner and Schneider 2003; Kirchgässner and Kübler 1992) and the shadow economy (Kirchgässner 1983b, 2017b).

Kirchgässner was very active in the scientific community. Aside from his involvement and service for the EPCS, he was president of the Swiss Society of Economics and Statistics from 2008 to 2011 and held various positions in the German Economic Association, particularly after a new ethical code was introduced during Kirchgässner's service as ombudsman from 2012 to 2016. He was a member of the German Academy of Natural Scientists Leopoldina (National Academy of Sciences) from 2001, finally as chairman of the Humanities, Social and Behavioral Sciences group. He held visiting positions, among others, at George Mason University (1996), Australian National University (2003), Carleton University, Ottawa (2003) and as Fellow at the Institute of Advanced Study in Berlin (2013-2014). I remember with gratitude his constructive role in organizing a visit by Jim Buchanan as a Hayek Memorial Visiting Professor at the University of St. Gallen in December 1999 and January 2000.

Kirchgässner did not only have broad research interests, he remained devoted to those interests throughout his career. Above all, however, he was devoted to rigorous scientific standards. He remained incorruptible and principled in scientific analysis. He particularly 
disliked pompous incompetence. His comments were dreaded, in particular when he started saying that the presenter's analysis was plain wrong. He was not only dedicated to research, but also a true and reliable friend.

Kirchgässner passed away on April 1, 2017, just 2 weeks before his 69th birthday, after a long and severe illness. In great dignity, he accepted his fate of leaving earlier than expected. Economics, in particular public choice, lost a towering figure, an influential scholar and a great mind. We miss him already.

\section{References}

Brennan, G., \& Buchanan, J. M. (1980). The power to tax: Analytical foundations of a fiscal constitution. Cambridge: Cambridge University Press.

Brennan, G., \& Lomasky, L. (1993). Democracy and decision: The pure theory of electoral preference. Cambridge: Cambridge University Press.

Buchanan, J. M., \& Tullock, G. (1962). The calculus of consent: Logical foundations of constitutional democracy. Ann Arbor: University of Michigan Press.

Dorn, D., Fischer, J. A. V., Kirchgässner, G., \& Sousa-Poza, A. (2008). Direct democracy and life satisfaction revisited: New evidence for Switzerland. Journal of Happiness Studies, 9, 227-255.

Downs, A. (1957). An economic theory of democracy. New York: Harper.

Feld, L. P., Fischer, J., \& Kirchgässner, G. (2010a). The effect of direct democracy on income redistribution: Evidence for Switzerland. Economic Inquiry, 48, 817-840.

Feld, L. P., \& Kirchgässner, G. (1999). Public debt and budgetary procedures: Top down or bottom up? Some evidence from Swiss municipalities. In J. M. Poterba \& J. von Hagen (Eds.), Fiscal institutions and fiscal performance (pp. 151-179). Chicago: Chicago University Press and NBER.

Feld, L. P., \& Kirchgässner, G. (2000a). Official and hidden unemployment and the popularity of the government: An econometric analysis of the Kohl government. Electoral Studies, 19, 333-347.

Feld, L. P., \& Kirchgässner, G. (2000b). Direct democracy, political culture, and the outcome of economic policy: A report on the Swiss experience. European Journal of Political Economy, 16, 287-306.

Feld, L. P., \& Kirchgässner, G. (2001a). Does direct democracy reduce public debt? Evidence from Swiss municipalities. Public Choice, 109, 347-370.

Feld, L. P., \& Kirchgässner, G. (2001b). The political economy of direct legislation: Direct democracy in local and regional decision-making. Economic Policy, 33, 329-367.

Feld, L. P., \& Kirchgässner, G. (2003). The impact of corporate and personal income taxes on the location of firms and on employment: Some panel evidence for the Swiss cantons. Journal of Public Economics, 87, 129-155.

Feld, L. P., \& Kirchgässner, G. (2008). On the effectiveness of debt brakes: The Swiss experience. In R. Neck \& J.-E. Sturm (Eds.), Sustainability of public debt (pp. 223-255). Cambridge/London: MIT Press.

Feld, L. P., Kirchgässner, G., \& Schaltegger, C. A. (2010b). Decentralized taxation and the size of government: Evidence from Swiss state and local governments. Southern Economic Journal, 77, $27-48$.

Feld, L. P., Kirchgässner, G., \& Schaltegger, C. A. (2011). Municipal debt in Switzerland: New empirical results. Public Choice, 149, 49-64.

Kirchgässner, G. (1976). Rationales Wählerverhalten und optimales Regierungsverhalten, Ein Beitrag zur Untersuchung des Zusammenhangs zwischen dem wirtschaftlichen und dem politischen Teilsystem moderner demokratischer Gesellschaften. Dissertation, University of Konstanz.

Kirchgässner, G. (1981). Einige neuere statistische Verfahren zur Erfassung kausaler Beziehungen zwischen Zeitreihen, Darstellung und Kritik. Göttingen: Vandenhoeck and Ruprecht.

Kirchgässner, G. (1983a). The political business cycle if the government is not myopic: An integration of the long-run and short-run models of the political business cycle. Mathematical Social Sciences, 4, $243-260$.

Kirchgässner, G. (1983b). Size and development of the West German shadow economy, 1955-1980. Zeitschrift für die gesamte Staatswissenschaft/Journal of Institutional and Theoretical Economics (JITE), 139, 197-214.

Kirchgässner, G. (1984a). Optimale Wirtschaftspolitik und die Erzeugung politischökonomischer Konjunkturzyklen. Meisenheim: Hain. 
Kirchgässner, G. (1984b). On the theory of optimal government behavior. Journal of Economic Dynamics and Control, 8, 167-195.

Kirchgässner, G. (1985a). Causality testing of the popularity function: An empirical investigation for the Federal Republic of Germany, 1971-1982. Public Choice, 45, 155-173.

Kirchgässner, G. (1985b). Rationality, causality, and the relation between economic conditions and the popularity of parties: An empirical investigation for the Federal Republic of Germany, 1971-1982. European Economic Review, 28, 243-268.

Kirchgässner, G. (1991a). On the relation between voting intention and the perception of the general economic situation: An empirical analysis for the Federal Republic of Germany, 1972-1986. European Journal of Political Economy, 7, 497-526.

Kirchgässner, G. (1991b). Homo Oeconomicus: Das ökonomische Modell individuellen Verhaltens und seine Anwendung in den Wirtschafts- und Sozialwissenschaften. 4th edition 2013, Tübingen: Mohr Siebeck.

Kirchgässner, G. (1992). Towards a theory of low-cost decisions. European Journal of Political Economy, 8, 305-320.

Kirchgässner, G. (1993). Testing weak rationality of forecasts with different time horizons. Journal of Forecasting, 12, 541-558.

Kirchgässner, G. (1996). Ideologie und Information in der Politikberatung: Einige Bemerkungen und ein Fallbeispiel. Hamburger Jahrbuch für Wirtschafts- und Gesellschaftspolitik, 41, 9-41.

Kirchgässner, G. (2000). Probabilistic voting and equilibrium: An impossibility result. Public Choice, 103, $35-48$.

Kirchgässner, G. (2008). Homo Oeconomicus: The economic model of behaviour and its applications to economics and other social sciences. New York: Springer.

Kirchgässner, G. (2009). The lost popularity function: Are unemployment and inflation no longer relevant for the behaviour of German voters?, CESifo Working Paper No. 2882, Munich.

Kirchgässner, G. (2010). On minimal morals. European Journal of Political Economy, 26, 330-339.

Kirchgässner, G. (2013a). Fiscal institutions at the cantonal level in Switzerland. Schweizerische Zeitschrift für Volkswirtschaft und Statistik, 149, 139-166.

Kirchgässner, G. (2013b). The weak rationality principle in economics. Schweizerische Zeitschrift für Volkswirtschaft und Statistik, 149, 1-26.

Kirchgässner, G. (2014a). On the political economy of public deficits and debt. German Economic Review, $15,116-130$.

Kirchgässner, G. (2014b). On the process of scientific policy advice-with special reference to economic policy. CESifo Working Paper No. 5144, Munich.

Kirchgässner, G. (2016a). Voting and popularity. In R. Congleton, B. Grofman, \& S. Voigt (Eds.), The Oxford handbook of public choice. Oxford: Oxford University Press. Forthcoming.

Kirchgässner, G. (2016b). Direct democracy: Chances and challenges. Open Journal of Political Science, 6 , 229-249. http://file.scirp.org/pdf/OJPS_2016042716372201.pdf.

Kirchgässner, G. (2017a). The debt brake of the German states: A faulty design? Constitutional Political Economy. doi:10.1007/s10602-017-9240-3.

Kirchgässner, G. (2017b). On estimating the size of the shadow economy. German Economic Review, 18, 99-111.

Kirchgässner, G., Feld, L. P., \& Savioz, M. R. (1999). Die direkte Demokratie: Modern, erfolgreich, entwicklungs- und exportfähig. Basel/München: Helbing and Lichtenhahn/Vahlen.

Kirchgässner, G., \& Kübler, K. (1992). Symmetric or asymmetric price adjustment in the oil market? An empirical analysis of the relations between international and domestic prices in the Federal Republic of Germany, 1972-1989. Energy Economics, 14, 171-185.

Kirchgässner, G., \& Meyer zu Himmern, A. (1997). Expected closeness and turnout: An empirical analysis for the German general elections, 1983-1994. Public Choice, 91, 3-25.

Kirchgässner, G., \& Müller, U. K. (2006). Are forecasters reluctant to revise their predictions? Some German evidence. Journal of Forecasting, 25, 401-413.

Kirchgässner, G., \& Pommerehne, W. W. (1976). The demand for fiscal decentralisation: Some preliminary findings. Sociologia Ruralis, 16, 208-219.

Kirchgässner, G., \& Pommerehne, W. W. (1996). Tax harmonization and tax competition in the European Union: Lessons from Switzerland. Journal of Public Economics, 60, 351-371.

Kirchgässner, G., \& Pommerehne, W. W. (1997). Public spending in federal states: A comparative econometric study. In P. Capros \& D. Meulders (Eds.), Budgetary policy modelling: Public expenditures (pp. 179-213). London/New York: Routledge.

Kirchgässner, G., \& Prohl, S. (2008). Sustainability of Swiss fiscal policy. Schweizerische Zeitschrift für Volkswirtschaft und Statistik, 144, 57-83. 
Kirchgässner, G., \& Schimmelpfennig, J. (1992). Closeness counts if it matters for electoral victory: Some empirical results for the United Kingdom and the Federal Republic of Germany. Public Choice, 73, 283-299.

Kirchgässner, G., \& Schneider, F. (2003). On the political economy of environmental policy. Public Choice, 116, 369-396.

Kirchgässner, G., \& Wolters, J. (1987). U.S._-European interest rate linkage: A time series analysis for West Germany, Switzerland, and the United States. The Review of Economics and Statistics, 69, 675-684.

Kirchgässner, G., \& Wolters, J. (1992). Implications of temporal aggregation on the relation between two time series. Statistische Hefte/Statistical Papers, 33, 1-19.

Kirchgässner, G., \& Wolters, J. (1995). Interest rate linkages in Europe before and after the introduction of the European Monetary System. Empirical Economics, 20, 435-454.

Kirchgässner, G., \& Wolters, J. (2007). Introduction to modern time series analysis. Berlin: Springer. 